\title{
Dysfunctional Audit Behavior and Sign Off Premature Audit Procedures: Case Study of Jakarta Public Accounting Firm
}

\author{
Trinandari P. Nugrahanti* \\ IKPIA Perbanas Institute \\ J1 Perbanas, Karet Kuningan, Setiabudi, Jakarta Indonesia \\ Nurfaidzah \\ IKPIA Perbanas Institute \\ J1 Perbanas, Karet Kuningan, Setiabudi, Jakarta Indonesia
}

\begin{abstract}
This study aims to analyze the influence of factors that could result in high termination of audit procedures for premature signing and dysfunctional audit behavior on auditors working in public accounting firms. Factors considered include time pressure, locus of control and turnover intentions for terminating premature sign off audit procedures and how they affect the dysfunctional audit behavior of auditors working in the public accounting firms in Jakarta City Indonesia. Data obtained from the questionnaire to the external auditor were distributed to 85 respondents. The analysis technique uses path analysis with the SmartPLS program. The results showed that locus of control was positively related to premature signs of audit procedures while time pressure and turnover intention do not affect. Time pressure is positively related to dysfunctional audit behavior while locus of control, turnover intention and premature signs of audit procedures do not affect. The premature signing audit procedure cannot mediate between the effects of time pressure, locus of control and turnover intentions to dysfunctional audit behavior. The public accounting firm may evaluate the policies undertaken to overcome the possibility of premature discontinuation of audit procedures resulting in a distortion of auditor behavior to degrade audit quality. Keywords: Dysfunctional Audit Behavior, Premature Sign off Audit Procedures, Time Pressure, Locus of Control, Turnover Intention
\end{abstract}

DOI: $10.7176 /$ RJFA/11-6-03

Publication date:March $31^{\text {st }} 2020$

\section{Introduction}

One of the services provided by the public accounting firm (KAP) is an attestation. Attestation is a category of assurance services, where these services are independent professional services that improve the quality of information for decision-makers. Besides, to go to public companies, many private companies are requesting their annual financial statements to be audited for loans from banks and other financial institutions. Governments and nonprofit entities often undergo audits to meet the requirements of the lender or funding source (Arens, et al., 2017: 13-16).

The examination conducted by the finance ministry to the public accounting firm located in Jakarta with a sample of $38 \mathrm{KAP}$, the result shows that many violations against Standard Professional Public Accountants (SPAP). Based on the results of the examination conducted Financial Development Professional Center (PPPK). The SPAP violations committed include SA 326 on audit evidence, SA 311 on planning and supervisor, SA 333 on management representation and SA 230 on the use of professional proficiency meticulously and thoroughly in the performance of the auditor's work. The public accounting firm (KAP) which is subject to freezing sanction in 2014 is KAP Drs. Dharma Surjadi Latief, MM with the frozen period for 3 months (pppk.kemenkeu.go.id, 2014)

The above case is a deviation that can reduce audit quality. Another example that may reduce audit quality is the premature termination of audit procedures. This is a practice when the auditor documents the audit procedure completely without actually doing it or ignoring some required audit procedures but the auditor may give an opinion on a financial statement (Shapeero et al, 2003; Nugrahanti, 2012). Research Alderman and Deitrick (1982) proves that $31 \%$ of auditors recognize the existence of audit irregularities in the form of premature sign-off. Kelley and Margheim (1990) found that 54\% of auditors ever deviated audit behavior in the form of direct action that could reduce audit quality. Rhagunatan (1991), 55\% of auditors claimed to have deviated audit behavior in the form of premature sign-off. Oatley and Pierce (1996) found that $60 \%$ of auditors claimed to have deviated audit behavior in the form of premature sign-off. Malone and Robert (1996), 49.5\% of auditors have ever deviated audit behavior in the form of actions that can directly reduce audit quality. Coram, $\mathrm{Ng}$, and Woodliff (2003) found $62.5 \%$ of auditors claimed to have deviated audit behavior by actions that could directly reduce audit quality.

Based on the background that has been described, the purpose of this study is to identify and analyze factors such as time pressure, locus of control and turnover intentions that cause auditory behavior deviations through termination of early audit procedures. The benefits of this study are for public accounting firms to replace existing 
policies to prevent the submission of regulations for premature termination of audit procedures that address auditor policy deviations and for auditors to improve professionalism in carrying out audit procedures under Public Accountant Standards (SPAP) to improve audit quality.

\section{Literature Review and Hypotheses Development}

Behavioral accounting theory developed based on Hopwood's thinking (1974) Accountants, operations researchers and management experts have developed psychological and social psychological factors including control issues. The science of sociology and psychology is also concentrated on control as well as social and personal phenomena. This research uses 2 (two) theories as to the base of hypothesis development that is attributed to theory and behavioral accounting theory. Heider's (1958) attribution is the process of concluding the motives, intentions, and characteristics of others by looking at their apparent behavior. One's behavior can be inferred because it is caused by the strength of the environment or internal strength. The strength of the environment consists of pressing situation factors, resulting in certain behaviors. Internal power is seen as a result of the abilities and efforts that a person demonstrates. The concept of behavior was originally a major field study in psychology and social psychology, but psychological and psychological factors such as motivation, perception, attitudes, and personality were highly recommended with accounting (Siegel and Marconi 1986: 28).

Premature sign off Audit Procedures. One of the behaviors that can degrade the quality of the audit is the premature cessation of audit procedures (Coram, $\mathrm{Ng}$, \& Woodliff, 2003). Premature sign-off occurs when the auditor does not complete the audit steps or describes the number of audit verifications. This action relates to the termination of the necessary audit procedures, performs incomplete work and ignores the audit procedures but they dare to express opinions on their audited financial statements. Premature sign off audit procedures directly affects audit quality and violates standard professional auditors. Shapeero et al, (2003) concluded that failure in auditing is more frequent because of the deletion of important audit procedures. The auditor's probability of making false judgments and opinions will be higher if one or more steps in the audit procedure are eliminated. Some reasons why auditors practice premature discontinuation of audit procedures include: (1) limited auditing periods established, (2) assumption that audit procedure are not important, (3) procedures are not material audits, (4) audit procedures (5) limited timing of audit reporting, and (6) auditor's boredom factor (Alderman and Derick, 1982; Raghunathan, 1991, Wahyudin et al., 2011).

Time pressure Kelley \& Seiler (1982), a time budget has a definition as a budgeted time to implement the steps in each audit program. According to Kelley, et al. (1982), time budget pressure is a condition that occurs where the budgeted time is less than the time available to complete the established audit procedures. Understanding the time budget pressure according to DeZoort (1998), namely the pressure arising from the limitations on resources can be allocated to perform and complete the audit task. Limited resources for various situations, including profitability issues, limited auditor personnel, and cost constraints. Based on the above definition, it can be concluded that time pressure is a condition where the auditor gets pressure to complete the audit procedure on time based on the budgeted agreement. Auditors who are facing time pressures can respond in two ways: to work harder, or more efficiently, over time. When required, the auditor may request additional time on the supervisor (Otley \& Pierce, 1996), and use more efficient audit procedures (Coram, Ng, \& Woodliff, 2003). Time pressure is often seen as degrading performance, but when time allocation is done properly it acts as a control mechanism and an indicator of success for the performance of auditors and public accounting firms (Cook \& Kelley, 1991; Nugrahanti, 2018). The results of Waggoner and Cashell (1991) find that time pressure hurts the auditor's performance, leaving the auditor to stop the audit procedure. Research Coram, $\mathrm{Ng}$, \& Woodliff (2003), found that along with the increasing budget tightening, the practice of premature discontinuation of auditing procedures is also increasing. Rhode, J. (1978), Kelley \& Seiler (1982), and Nugrahanti (2018) mentioned that the pressure over audit procedures. Based on the description above, then the hypothesis that can be prepared is as follows:

H1: Time pressure has a positive effect on the premature sign of audit procedures.

Locus of control is a condition in which individuals believe they can master their destiny (Shapeero, et al, 2003). Control focus is divided into two, namely internal and external control locus. The focus of internal control regulates the perception that both positive and negative events occur as a consequence of acts of self-action. While the locus of external control refers to the belief that an event is beyond its self-control such as fate, likelihood (Shapeero, et.al, 2003). The locus of control according to the concept developed by Spector (1988), suggests that individuals develop expectations about their success depending on their behavior or being controlled by outside parties. Individuals who have an external locus of control, believe they can not control the events or outcomes they achieve. While individuals who have an internal locus of control tend to link the results with their own business or people believe that events are under their control.

According to Spector (1988), some things that indicate an external locus of control are (a) getting the right job is a good thing, (b) getting an award is a fortune, (c) to get a job there must be a friend or acquaintance that helps, (d) Promotion is a fortune, (e) to find a suitable job, acquaintance or friend is more important than ability, (f) to get what you want, someone must know the right, (g) person, (h) to be successful requires good luck, (i) luck 
is a factor that distinguishes people who succeed and fail. Individuals who have an external locus of control are individuals who believe they cannot control events and outcomes (Spector 1988 in Donelly et al., 2003). Research conducted by Suryadi (2002) shows that locus of control does not affect the premature termination of audit procedures. However, inconsistent with research conducted by Donelly et al (2003) indicates that the external locus of control significantly affects the premature cessation of the audit procedure. Thus, the higher the external locus of control the auditor has, the higher the auditor's tendency to practice premature discontinuation of audit procedures, and vice versa. This result is because the auditor with a high locus of control has not been able to control the results to be achieved and tend to perform various ways, such as manipulation or fraud to achieve his personal goals. Based on the description above, then the hypothesis that can be prepared is as follows:

$\mathrm{H} 2$ : Locus of Control has a positive effect on premature sign off audit procedures.

Turnover intentions are defined as a willingness to awareness and neglect for the organization (Tett and Mayer, 1993). Organizational stopovers (intentions) reflect the desire (consciousness or deliberate) of individuals to forget work and seek alternative employment elsewhere (Setiawan and Ghozali, 2006: 15). The desire to quit the work of the organization is influenced by employee dissatisfaction at work. According to Robbins (1998), job dissatisfaction with workers can be expressed in a variety of ways such as leaving jobs, complaining, defending, stealing company or organization property, avoiding some of their job responsibilities and others. Anita (2014) turnover intentions are the desire (consciousness or deliberate) of the auditor to leave the organization or look for alternative jobs elsewhere, The desire of auditors to exit the KAP can cause problems mainly related to auditor behavior problems. The result of the research is a positive turnover intention relationship with premature termination of audit procedures. Auditors with a desire to leave the company are more likely to engage in premature sign-offs. Margheim et al. (2005) and Donelly et al (2003), also shows that turnover intentions have a significant effect on premature termination of audit procedures. Based on the description above, then the hypothesis that can be prepared is as follows:

H3: Turnover intentions have a positive effect on premature sign off audit procedures

Dysfunctional (deviation) audit behavior is a result of the other party's response to the attitude of one's actions, a deviation is generally an act that violates certain rules. Usually, such deviant acts are perceived to be driven by something that lies in the social situations experienced by deviators (Howard S.Becker 1996: 8-9). In the Statement on Auditing Standard (SAS) issued by the American Institute of Certified Public Accountants (AICPA), SAS No. 82 leads the auditor to accept more responsibility by increasing the level of audit testing regardless of possible fraudulent risks in the financial statements. SAS No. 82 states that the auditor's attitude in accepting dysfunctional behavior is an indicator of actual dysfunctional behavior. Some dysfunctional audit behaviors that jeopardize audit quality are altering/replacement of audit procedures and premature sign-offs while underreporting of time affects the audit results indirectly. Inadequate evidence acquisition, inaccurate processing, and errors from audit stages are also the impact of dysfunctional audit behavior. Acceptance of underreporting time facing professional responsibilities, such as time pressure and supervisory style (Donnelly et al., 2003; Nugrahanti, 2018). Besides, the altering/replacement of the audit procedure is the replacement audit procedure that has been set in auditing standards. According to Gable and Dangello (1994), this has a direct effect on audit quality and may alter audit outcomes. Replacement audit procedures occur because the original audit procedure is not necessary, the auditor feels that the audit will not dominant is the time pressure that forces the auditors to change audit procedures that can speed up audit completion. Dewi's research (2015) states that time pressure has a positive effect on dysfunctional audit behavior. The results showed that the higher the time pressure level, the auditor's acceptance level of dysfunctional audit behavior is also higher where the tendency of the auditor will perform the dysfunctional audit behavior in auditing the financial statements will be higher. The results of the study are consistent with previous similar studies including Dewi's (2015), and Supriyanto (2009). This study reinforces the notion that auditors engage in dysfunctional audit behavior (underreporting of time, premature sign-off, altering or replacing of audit procedures) occurs in situations where the auditor considers themselves less able to achieve the outcomes they expect due to the pressure imposed by management in Determine the time budget. Based on the description above, then the hypothesis that can be prepared is as follows:

H4: Time pressure positively affects dysfunctional audit behavior.

The results of Evanauli \& Nazaruddin (2010) found that the external locus of control positively affects dysfunctional audit behavior. This is in line with Donnelly's research et. Al. (2003), Shapeero, et al (2003), and Silaban (2011) found that there was a significant positive relationship between the external locus of control and the dysfunctional behavior of the audit. Results Individuals who have an external locus of control when they feel inadequate to get the strong support they need to survive in an organization, they have the potential to try to manipulate colleagues or other objects as their defense needs. This then leads to dysfunctional audit behavior. The results of this study differ from Kartika et al. (2007) who examined employee performance relations and acceptance of dysfunctional audit behavior by using locus of control as an antecedent variable. The results show that the internal locus of control has a negative influence on the acceptance of audit irregularities. Based on the description above, then the hypothesis that can be prepared is as follows: 
H5: Locus of Control positively affects dysfunctional audit behavior.

Research conducted by Aranya \& Ferris (1984), and Jannah et al (2016), shows that there is a positive relationship between the desire to stop working (turnover intentions) with acceptance of behavioral deviations in the audit with the condition of locus of external control and commitment to the organization. This suggests that the desire to stop working can make a person less concerned about what he does in his organization so that it can be more involved in behavioral aberrations due to a decrease in fear of possible sanctions if such behavior is detected. Juliyanty Sidik Tjan (2019), state that turns over intention proves that it can mediate the influence of task complexity on dysfunctional audit behavior. Based on the description above, then the hypothesis that can be prepared is as follows:

H6: Turn over intentions have a positive effect on dysfunctional audit behavior

Shapeero et. Al. (2003) states that audit failure is often caused by the elimination of important audit procedures or inadequate audit procedures for some items. Research conducted by Malone and Roberts (1996), and Coram, Ng, \& Woodliff (2003), suggests that the act of deviation done by an auditor and can reduce the quality of the audit one of them by making the cessation of premature audit procedures (premature sign-off audit procedures). Based on the description above, then the hypothesis that can be prepared is as follows:

H7: Premature sign off audit procedures positively affects the dysfunctional audit behavior

Some factors that may affect an auditor to perform acts of irregularity caused by factors of personal characteristics of auditors (internal factors) as well as site factors when conducting an audit (external factors). The purpose of this research is to know how the influence of independent variable consist of time pressure, locus of control and turnover intentions to dysfunctional audit behavior through premature sign off audit procedures as an intervening variable.

\section{Methodology Research}

The population used in this study is the auditor who works in the public accounting firm located in Jakarta city in Indonesia. The sampling method in this research is convenience sampling, Questionnaires were sent to 115 respondents, 85 questionnaires were returned and 85 questionnaires could be processed. The response rate of the respondents was $73.9 \%$. Based on the above calculation, the minimum samples in this population is 85 respondents.

In this study data analysis using Partial Least Square (PLS) approach. PLS is a model of Structural Equation Modeling (SEM) equations based on components or variants. According to Ghozali (2006), PLS is an alternative approach that shifts from a Covarian-based SEM approach to a variance-based. SEM-based covariance generally tests the causality/theory while PLS is the more predictive model. PLS is a powerful analytical method (Ghozali, 2006) because it is not based on many assumptions. For example, the data should be normally distributed, the sample should not be large. Also, can be used to confirm the theory, PLS can also be used to explain the presence or absence of relationships between latent variables. PLS can simultaneously analyze constructs formed with reflective and formative indicators. This research uses PLS, thus the sample size based on the PLS rule will be 30100 (Ghozali, 2006) or 5-10 multiplied by the number of indicator questions (Ferdinand, 2002). This research has 32 indicator questions. 
Tabel 1. Operational Research Variables

\begin{tabular}{|c|c|c|}
\hline Variable & Dimension & Indicator \\
\hline \multirow[t]{4}{*}{ Time Pressure } & Time & Lack of audit time budget \\
\hline & Limitations personnel & Audit personnel limitations \\
\hline & Budget & Cost constraints \\
\hline & Audit Procedure & Constraints in the implementation of audit procedures \\
\hline \multirow[t]{3}{*}{ Locus of Control } & Luck & Getting a job is good luck \\
\hline & Relation & $\begin{array}{l}\text { Connection factors and expertise in obtaining jobs and } \\
\text { jobs }\end{array}$ \\
\hline & Appreciation & Award earned \\
\hline \multirow[t]{2}{*}{ Turnover Intentions } & Leave the organization & $\begin{array}{l}\text { Individual desire in the form of a desire to get out of } \\
\text { the organization }\end{array}$ \\
\hline & Job dissatisfaction & Dissatisfaction in working \\
\hline \multirow[t]{7}{*}{$\begin{array}{l}\text { Premature sign off } \\
\text { audit procedures }\end{array}$} & $\begin{array}{l}\text { Audit planning in } \\
\text { understanding the client's } \\
\text { business }\end{array}$ & Consideration of client's internal control system \\
\hline & $\begin{array}{l}\text { Assessment of material } \\
\text { misstatement at the } \\
\text { assertion }\end{array}$ & Consideration of assertion information \\
\hline & \multirow{5}{*}{$\begin{array}{l}\text { Audit evidence is } \\
\text { incomplete }\end{array}$} & Analytical procedures \\
\hline & & Confirmation \\
\hline & & Use of management representation \\
\hline & & Physical calculation \\
\hline & & $\begin{array}{l}\text { Audit evidence such as reperformance, recalculate, } \\
\text { and observation }\end{array}$ \\
\hline \multirow{7}{*}{$\begin{array}{l}\text { Dysfunctional audit } \\
\text { behavior }\end{array}$} & \multirow{3}{*}{$\begin{array}{l}\text { Altering/replacement of } \\
\text { audit procedure }\end{array}$} & Pressure time \\
\hline & & Supervisor style \\
\hline & & $\begin{array}{l}\text { Good internal control and audit evidence are easily } \\
\text { available }\end{array}$ \\
\hline & \multirow[t]{4}{*}{$\begin{array}{l}\text { Altering/replacement of } \\
\text { audit procedure }\end{array}$} & $\begin{array}{l}\text { Auditing procedures that have been done before are } \\
\text { not necessary }\end{array}$ \\
\hline & & $\begin{array}{l}\text { There is an audit procedure done before there is a } \\
\text { problem to obtain evidence. }\end{array}$ \\
\hline & & Previously planned audit procedures cannot find fault \\
\hline & & $\begin{array}{l}\text { There is high time pressure to complete the audit } \\
\text { process }\end{array}$ \\
\hline
\end{tabular}

Source: Data processed by researchers

Data analysis technique on hypothesis testing using path analysis is an analytical technique used to test direct and indirect influence between two or more variables or in other words the theoretical relationship between variables, and data processing using the SmartPLS program. Path analysis is used to test the influence of intervening variables and is an extension of multiple linear regression analysis to estimate the causality relationship between the predetermined variable based on theory. This section described the results of hypothesis testing with SEM-PLS analysis techniques.

\section{Results and Discussions}

Structural Model Test (Inner Model). Inner model or structural model testing is performed to see the relationship between construct, significance value and R-square of the research model. The structural model is evaluated by using R-square for the t-test dependent construct as well as the significance of the structural path parameter coefficients structural test seen from two equations is one equation to see the influence of each independent variable to the dependent variable $\mathrm{Y}$ while the two equations to see the effect of each independent variable to variable Z. 
Figure 1. Overall Structural Model

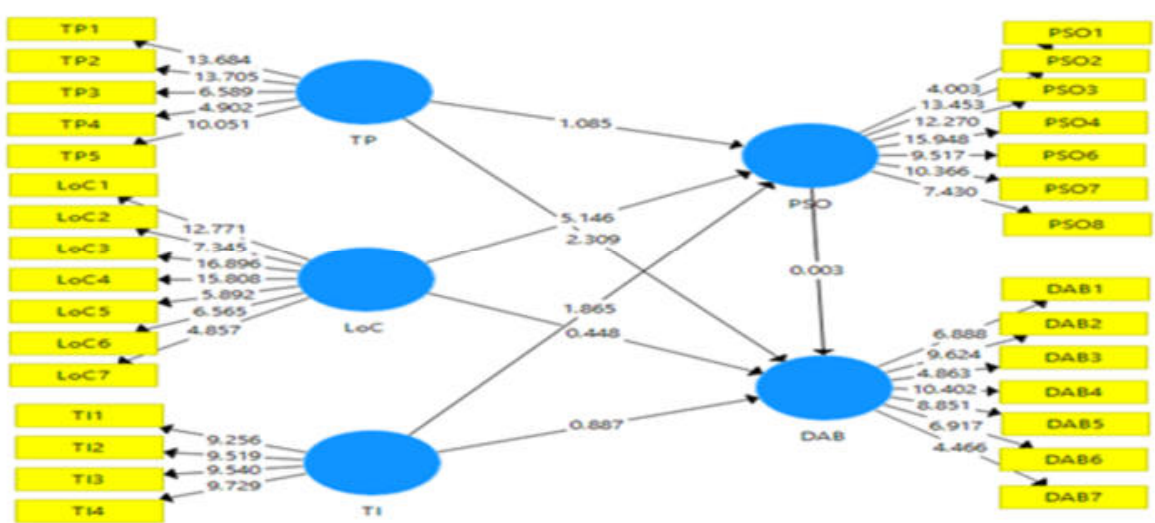

Source: Data processed by researchers

Figure 2. Structural Model of Equation I

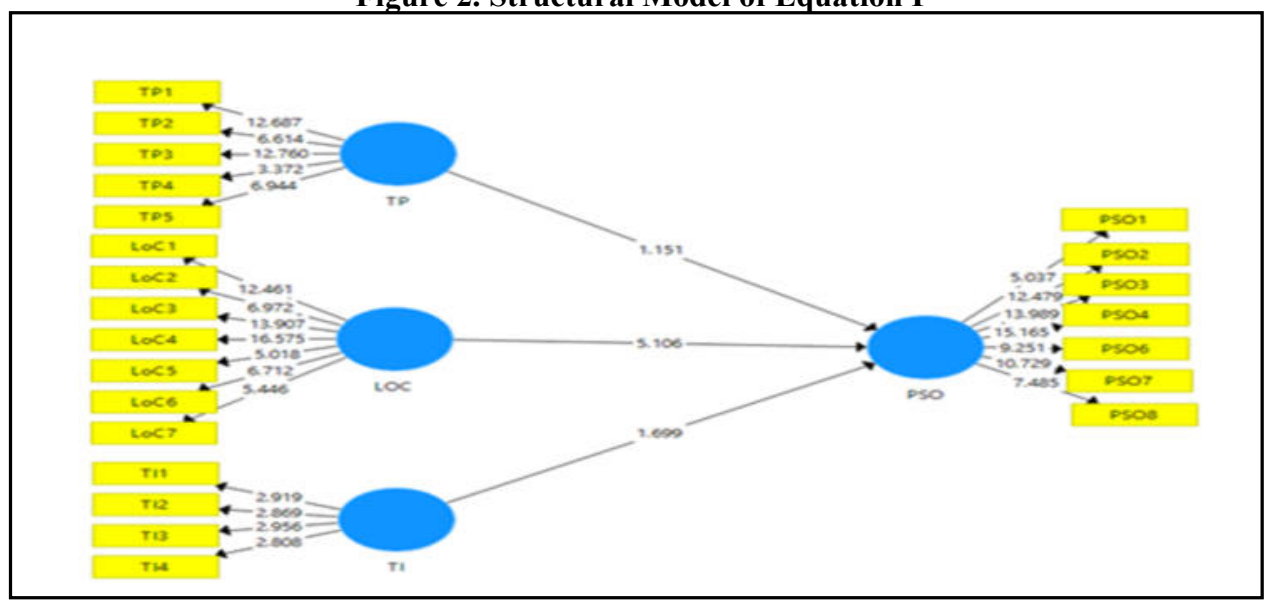

Source: Data processed by researchers

Figure 3. Structural Model of Equation II

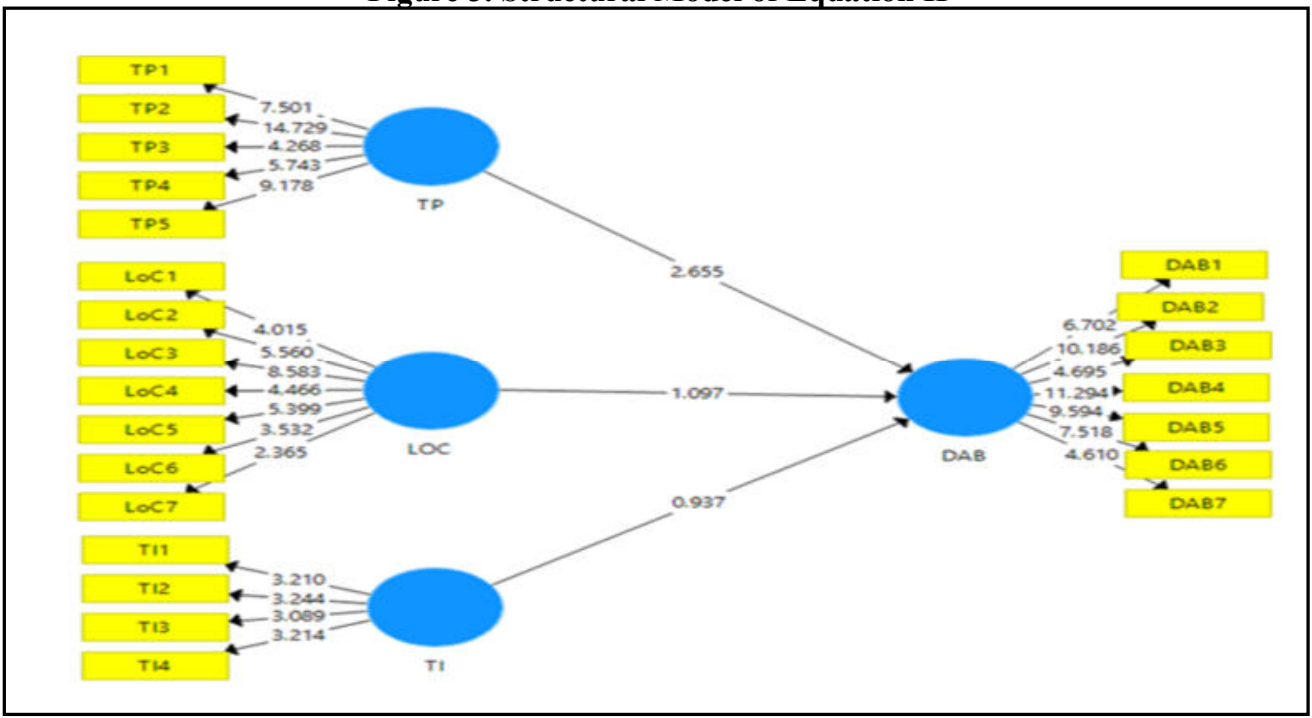

Source: Data processed by researchers 
In assessing the model with PLS begins by looking at R-square for each dependent latent variable. Table 2. is the result of R-square estimation using SmartPLS.

Table 2. Nilai $R$-square

\begin{tabular}{|c|c|c|}
\hline Variable & $R$ Square & $R$ Square Adjusted \\
\hline PSO & 0,323 & 0,298 \\
\hline DAB & 0,182 & 0,142 \\
\hline
\end{tabular}

Source: SmartPLS data processing results

Table 2. above the amount of adjusted $r$ square value (PSO) of 0.298 . This means that $29.8 \%$ of the variations of the four variables are time pressure, a locus of control and turnover intention which can be explained by the variation of independent variables ie premature sign off audit procedures. While the rest $(100 \%-29.8 \%=70.2 \%)$ is explained by other variables not proposed in the study. While for independent variable dysfunctional audit behavior the value of adjusted $r$ square (DAB) is 0,142 . This means $14.2 \%$ variation from the five variables ie time pressure, a locus of control, turnover intention and premature sign off audit procedures which can be explained by variations of independent variables dysfunctional audit behavior. While the rest $(100 \%-14.2 \%=85.8 \%)$ is explained by other variables not proposed in the study.

Hypotheses testing. The significance of estimated parameters provides very useful information on the relationship between research variables. The basis used in testing the hypothesis is the value contained in the output of the result for inner weight. This study has several hypotheses that have been tested. This section discusses the interpretation of the results of research that has been done and useful to answer the problems and objectives of the research. Table 3. provides estimation output for structural model testing.

Table 3. Result for inner weights

\begin{tabular}{|c|l|l|l|l|}
\hline & $\begin{array}{l}\text { Original } \\
\text { Sample }\end{array}$ & $\begin{array}{l}\text { Sample } \\
\text { Mean }\end{array}$ & $\begin{array}{l}\text { Standard } \\
\text { Deviation }\end{array}$ & $\begin{array}{l}\text { t-test } \\
\text { Statistics }\end{array}$ \\
\hline TP -> PSO & 0,129 & 0,127 & 0,119 & 1,085 \\
\hline LoC -> PSO & 0,491 & 0,504 & 0,095 & 5,146 \\
\hline TI -> PSO & 0,190 & 0,190 & 0,102 & 1,865 \\
\hline TP -> DAB & 0,357 & 0,367 & 0,155 & 2,309 \\
\hline LoC -> DAB & 0,080 & 0,090 & 0,178 & 0,448 \\
\hline TI -> DAB & $-0,110$ & $-0,112$ & 0,124 & 0,887 \\
\hline PSO -> DAB & $-0,001$ & 0,007 & 0,163 & 0,003 \\
\hline
\end{tabular}

Source: SmartPLS data processing results

The influence of Time Pressure on Premature Sign Off. The results of the first hypothesis test showed that the relationship of time pressure variable (TP) with premature sign off (PSO) showed a coefficient value of 0.129 with a $t$-test value of 1.085 . The value is smaller than $t$ table $(1,960)$. This result means that time pressure has a positive but not significant relationship to premature sign-off. This means Hypothesis 1 is rejected. Based on the test results show that time pressure variable does not affect premature sign-off. From the results obtained from this study assumes that an auditor who has high time pressure does not necessarily make early audit termination. Although an auditor feels time pressures but does not neglect the established audit procedures so that they continue to perform the audit procedures as appropriate. Time pressure variable does not influence premature sign off because most respondent in this research is junior auditor so in conducting audit they still carry out audit procedure which is assigned by senior audit. The results of this study following the results of research conducted Anita (2014), dan Wahyudin et al (2011) stated that time pressure does not affect the premature termination of audit procedures.

The influence of Locus of Control on Premature Sign Off. This result means that the locus of control has a positive and significant relationship to premature sign-off. The result of the second hypothesis test shows that the relationship of locus of control (LoC) with premature sign off (PSO) indicates the coefficient value of 0.491 with a t-test value of 5.146. The value is greater than $t$ table (1,960). This means Hypothesis 2 is accepted. Based on the test results show that the variable locus of control has a positive and significant influence on premature sign-off. From the results obtained from this study assumes that an auditor who has a high external locus of control will lead to the occurrence of audit procedures in the early stages. This is because auditors with a high external locus of control have not been able to control the results to be achieved and tend to perform various ways, such as manipulation or fraud to achieve personal goals. A junior auditor tends not to be able to control the results achieved because they do not have a high sense of responsibility for their work. It is this auditor's behavior that triggers premature discontinuation of audit procedures. The results of this study are consistent with previous research conducted by Shapeero, et al (2003), and Donelly et al (2003

The influence of Intent Turnover on Premature Sign Off. This result means that turnover intention has an insignificant positive relationship with premature sign-off. The result of the third hypothesis test shows that the relationship of turnover intention (TI) with premature sign off (PSO) indicates the coefficient value of 0.190 with 
the value of $t$ equal to 1.865 . The value is smaller than $t$ table $(1,960)$. This means Hypothesis 3 is rejected. Based on the test results show that the intent turnover variable has no significant effect on premature sign-off. This causes intentional turnover not to be positively associated with early audit termination because auditors still have a high level of idealism for their work as an auditor so that the auditor will do the tasks with which he/she is responsible as well as possible and perform the tasks under the procedures, rules or policies applicable. Most respondents are junior auditors tend to work longer hours because they want to have a good work experience for them. The results of this study are not in line with research conducted by Anita (2014).

The influence of Time Pressure on Dysfunctional Audit Behavior. The fourth hypothesis test result shows that the time pressure (TP) variable relationship with dysfunctional audit behavior (DAB) shows a path coefficient value of 0,375 with a t-test value equal to 2,309 . The value is greater than $t$ table $(1,960)$. This result means that time pressure has a positive and significant relationship to dysfunctional audit behavior. This means Hypothesis 4 is accepted. Based on the test results show that time pressure variable has a positive and significant influence on dysfunctional audit behavior. The results showed that the higher time budget pressure level, the auditor's acceptance of dysfunctional audit behavior is also higher where the tendency of auditors will perform dysfunctional audit behavior in auditing financial statements will be higher. A junior and senior auditor will accelerate their work due to pressure from their supervisor or manager so that accepting the acceleration of audit completion and the replacement of audit procedures to obtain audit evidence if the previous audit procedures do not get evidence to be more effective and efficient in time and audit costs. The results of the research are consistent with previous similar studies, among others, Dewi (2015), and Margheim et al. (2005).

The influence of Locus of Control on Dysfunctional Audit Behavior. This result means that the locus of control has a positive and insignificant relationship to the dysfunctional audit behavior. This means Hypothesis 5 is rejected. The value is smaller than $t$ table $(1,960)$. This result means that the locus of control has a positive and insignificant relationship to the dysfunctional audit behavior.

Based on the test results show that the variable locus of control has a positive influence and not significant to dysfunctional audit behavior. This indicates that someone who owns the locus of control is still rational to the work done. Respondents consider that although they feel they have a locus of control but do not ignore what they are responsible for. The results of respondents' answers tend to be neutral toward the luck factor. Respondents consider that the skills they possess are more important to produce good performance so that there will be an opportunity to earn rewards or equal rewards. The results of this study are in line with Shapeero, et al (2003), Donnelly et al. (2003), Spector (1988), Reed (1994), and Suryadi (2002) found that there was a significant positive relationship between the external locus of control and the dysfunctional behavior of the audit, but not in line with Mertha (2014).

The influence of Turnover Intention on Dysfunctional Audit Behavior. The result of the sixth hypothesis test shows that the relationship between turnover intention (TI) variable with dysfunctional audit behavior (DAB) shows the coefficient value of -0.110 with a value of 0.887 . The value is smaller than $t$ table $(1,960)$. This result means that turnover intention has an insignificant negative relationship with premature sign-off. This means Hypothesis 6 is rejected. Based on the test results show that the variable turnover intention does not have a significant effect on the dysfunctional audit behavior. This result shows that in reality there is no influence between an auditor who has a desire to change work with the auditor's acceptance level of dysfunctional audit behavior. Although respondents want to get out of the organization to get better imbalance, do not ignore what is their responsibility. The junior auditor who is the majority of respondents in this study is working to keep working because the public accounting firm provides training programs and tends to be satisfied in the work they are doing. The results of this study following research conducted by Evanauli \& Nazaruddin (2013) found that there was not a significant positive relationship between turnover intention and the dysfunctional behavior of the audit, but not in line with Malone dan Robert (1996) and, Anita (2014).

The influence of Premature Signs off on Dysfunctional Audit Behavior. The result of the seventh hypothesis test shows that the association of premature sign off (PSO) with dysfunctional audit behavior (DAB) shows the coefficient value of -0.001 with the value of $t$ equal to 0.003 . The value is smaller than $t$ table $(1,960)$. This result means that premature sign off has a negatively negative relationship to dysfunctional audit behavior. This means Hypothesis 7 is rejected. Based on the test results show that premature sign off does not have a significant effect on the dysfunctional audit behavior. This result shows that in reality there is no influence between audit failure is often caused by the elimination of important audit procedures or inadequate audit procedures for some items with the dysfunctional audit behavior. Research conducted by Malone and Roberts (1996), and Coram, $\mathrm{Ng}$, \& Woodliff (2003), Shapeero et. al. (2003) suggests that the act of deviation done by an auditor and can reduce the quality of the audit one of them by making the cessation of premature audit procedures (premature signoff audit procedures). 
Table 4.

Summary of Output Path Analysis from Direct Effect, Indirect Effect, and Total Effect

\begin{tabular}{|l|c|c|c|}
\hline \multicolumn{1}{|c|}{ Variable } & Total Effect & Indirect Effect & Direct Effect \\
\hline PSO <-------- TP & 0,129 & - & 0,129 \\
\hline PSO <------- LoC & 0,491 & - & 0,491 \\
\hline PSO <------- TI & 0,190 & - & 0,190 \\
\hline DAB <------- TP & 0,357 & $-0,000$ & 0,357 \\
\hline DAB <------- LoC & 0,079 & $-0,000$ & 0,079 \\
\hline DAB <------- TI & $-0,110$ & $-0,000$ & $-0,110$ \\
\hline DAB <------- PSO & $-0,001$ & - & $-0,001$ \\
\hline Jumlah & 1,135 & $-0,000$ & 1,135 \\
\hline
\end{tabular}

Source: SmartPLS data processing results

Based on Table 4. and the results of the path analysis above show the indirect effect of time pressure, a locus of control, turnover intention through premature sign off as intervening variable against dysfunctional audit behavior is smaller than the direct influence of dysfunctional audit behavior. That is, in this study premature sign off cannot be used as an intervening variable between time pressure, a locus of control, and turnover intention to dysfunctional audit behavior because the influence of each variable to dysfunctional audit behavior decreases when passing premature sign-off. In Table 4., it is explained that the direct effect of time pressure on dysfunctional audit behavior is 0.357 and the indirect effect through premature sign off is only $-0,000$. So the total influence of time pressure on dysfunctional audit behavior is 0.357 . The direct effect of the locus of control on the dysfunctional audit behavior is 0.080 and the indirect effect through premature sign off is only $-0,000$. So the total influence of locus of control on dysfunctional audit behavior is 0,080 . The direct effect of turnover intention on dysfunctional audit behavior is -0.110 and the indirect effect through premature sign off is only $-0,000$. So the total effect of turnover intention on dysfunctional audit behavior is -0.110 . The direct influence of time pressure, locus of control, turnover intention, and premature sign off simultaneously to dysfunctional audit behavior is 1.135 while the indirect influence of time pressure, locus of control, turnover intention simultaneously through premature sign off is 0.000 . It is known that premature sign off is not an intervening variable because there is no significant influence between premature sign off variables on dysfunctional audit behavior, besides the direct influence of premature sign off variables on dysfunctional audit behavior of $-0,001$ and indirect effect of 0,000 . This means that premature sign off is not an intervening variable between time pressure, locus of control, turnover intention to dysfunctional audit behavior. So that the influence of total time pressure, locus of control, turnover intention, and premature sign off against dysfunctional audit behavior is 1,135 .

\section{Conclusions}

The results that the hypothesis test indicated that the locus of control was positively related to the premature sign of audit procedures while the time pressure and turnover intention did not affect. The auditor possessing a high external locus of control tends to perform a variety of unfavorable ways because there is no high sense of responsibility for his job. Time pressure was positively related to the dysfunctional audit behavior while locus of control, turnover intention and the premature sign of audit procedures did not affect. The higher the time budget pressure level on the auditor so the higher the auditor will perform the dysfunctional audit behavior in auditing the financial statements. Premature sign off audit procedures cannot mediate between the influence of time pressure, the locus of control and turnover intention of dysfunctional audit behavior. This study will provide the following benefits auditors may improve the professionalism and audit quality provided in performing audit procedures under the Standards of Professional Public Accountants by avoiding the practice of irregularities by terminating audit procedures during audits. The public accounting firm (KAP) may evaluate the policies undertaken to overcome the possibility of premature discontinuation of audit procedures resulting in a distortion of auditor behavior to degrade audit quality. Future researchers are to develop research models by adding some variables, such as audit risk, organizational commitment, position, and employee performance.

\section{References:}

Alderman, C. W., and Deitrick, J. W. (1982). Auditors' perception of time budget pressures and premature signoffs: A replication and extension. Auditing: A Journal of Practice and Theory, 1(2), $54-68$.

Anita, Y. (2014). Influence of Time Pressure, Audit Risk, Locus of Control, and Turnover Intention on Premature Evaluation of Audit Procedures, JOM FEKON 1 (2), 1-15

Aranya, N., \& Ferris, K. R. (1984). Reexamination of Accountants' Organizational-Professional Conflict. The Accounting Review, 59(1), 1-15. Retrieved from https:/www.jstor.org/ stable/247113?seq=1\#page_scan_ tab_contents 
Arens, Alvin, Elder, J Randal, Mark S. Beasley, (2017). Auditing and Assurance Service : An Integrated Approach (15th ed.). London: Pearson Education Limited.

Boynton, William C, Raymond N. Johnson, Walter J. Kell. (2007). Modern Auditing. Seventh Edition (Original Modern Title Auditing, Seventh Edition).John Willey \& son.

Cook, E., \& Kelley, T. (1991). Auditor and time-budget. The CPA Journal, 58(7), pp 83-88.

Cook, E., and T. Kelley,(1991). "An International Comparison of Audit Time-Budget Pressures: The United States and New Zealand," The Women CPA, pp. 25-30, Spring.

Coram, P., Ng., J., \& Woodliff, D. (2003). A Survey of Time Budget Pressure and Reduced Audit Quality Among Australian Auditors. Australian Accounting Review, 13(1), 38-44. https://doi. org/10.1111/j.18352561.2003. tb00218.x

DeAngelo, L.E. (1981). Auditor Size and Auditor Quality. Journal of Accounting and Economics 3

Dewi, N. R., \& Wirasadena, P. W. I. (2015). Pengaruh Time Budget Pressure, Loc dan Task ComPlexity Pada Dysfunctional Audit Behaviour Akuntan Public. E-Jurnal Akuntansi Universitas Udayana, 11(1), 1-14. Retrieved from https://www.e-jurnal. com/2015/07/pengaruh-time-budget-pressure-loc-dan.html

Donelly, D. P., Quirin, J. J., \& O’Bryan, D. (2003). Auditor Acceptance of Dysfunctional Audit Behavior: An Explanatory Model Using Auditors Personal Characteristics. Behavioral Research in Accounting, 15(1), 87109. https:// doi.org/10.2308/bria.2003.15.1.87

DeZoort, F.T.(1998). Time Pressure Research in Auditing: Implications for Practice. Auditor's Report 22

Evanauli, R. P., \& Nazaruddin, I. (2013). Auditor's Acceptance of Dysfunctional Audit Behavior: A Personal Auditor's Characteristic Approach, Jurnal Akuntansi \& Investasi, 14, (2). Juli.

Ferdinand, A. (2002). Metode Penelitian Manajemen: Pedoman Penelitian Untuk Penulisan Skripsi (Tesis, dan Disertasi Ilmu Manajemen). BP Undip, Semarang.

Gable, M., and F. D'Angelo. (1994). "Locus of Control, Machiavellianism, and Managerial Job Performance. " Journal of Psychology. 128

Ghozali, Imam. (2009). Application of Multivariate Analysis with SPSS Program. Diponegoro University Publishing Agency: Semarang.

Hair, J., Hult, T., Ringle, C., \& Sarstedt, M. (2014). A Primer on Partial Least Squares Structural Equation Modeling (PLS-SEM). Thousand Oaks, CA: Sage Publications, Inc.

Hopwood, A.G.(1976). "Management Accounting and Human Behaviour" (Prentice Hall,1976).

Jannah, B. S., Baridwan, Z., \& Hariadi, B. (2016). The Determinant of Auditor Turnover Intention From Public Accounting Firm. Imperial Journal of Interdisciplinary Reseach (IJIR), 2, 537-547. Retrieved from https://www.

academia.edu/31853791/Determinant_Of_Auditors_Turnover_Intention_From_Public_Accounting_Firm_b inti_shofiatul_jannah.pdf

Juliyanty Sidik Tjan, Eko Ganis Sukoharsono, Aulia Fuad Rahman and Imam Subekti (2019). An analysis of the factors which influence dysfunctional auditor behavior. Problems and Perspectives in Management, 17(1), 257-267. DOI:10.21511/ppm.17(1).2019.22

Kelley. T., and L. Margheim. (1990). The Impact of Time Budget Pressure, Personality, and Leadership Variables on Dysfunctional Auditor Behavior. Auditing: A Journal of Practice and Theory

Kelley, T. and Seiler, R.E., (1982). Auditor stress and time budgets. The CPA Journal, December, $24-34$.

Margheim, L., Kelley, T., \& Pattison, D. (2005). An Empirical Analysis of the Effects of Auditor Time Budget Pressure and Time Deadline Pressure. Journal of Applied Business Research, 21(1). http://dx.doi.org/10.19030/jabr. v21i1.1497

Malone, Charles F., and Roberts, Robin W., (1996) Factors Associated with the Incidence of Reduced Audit Quality Behaviors. AUDITING: A JOURNAL OF PRACTICE \& THEORY,15 (2), Fall. Available at SSRN: https://ssrn.com/abstract $=2639$

Malle, B. F. (2011). Attribution Theories : How People Make Sense of Behavior, 72-95.

Mertha, I. M. (2014). Effect of Time Pressure, Audit Risk, Professional Commitment and Locus of Control on Premature Termination of Audit Procedure, 2, 185-196

Nugrahanti, Prasetyo Trinandari (2012). The Influence of Competence, Independence and Ethics for Auditors towards Audit Quality of Public Accountants in South Jakarta. Finance and Banking Journal, Indonesia Banking School Jakarta, 9 (1), 90-105.

Nugrahanti, Prasetyo Trinandari (2018). Audit Judgment Performance: The Effect of Performance Incentives, Obedience Pressures, and Ethical Perceptions. Journal of Environmental Accounting and Management, 6 (3), 225-234

Otley, D.T., and B.J. Pierce. (1996). The Operation of Control Systems in Large Audit Firms. Auditing: A Journal of Practice and Theory 15Ragunathan, B. 1991. Premature Signing-off of Audit Procedures: an Analysis. Accounting Horizons

Paino, Halil, Azlan Thani dan Syed Iskandar Zulkarnain Syid Idris. (2011). Attitude Toward Dysfunctional Audit 
Behavior: The Effect of Budget Emphasis, Leadership Behavior, and Effectiveness of Audit Review. Journal of Modern Accounting and Auditing. Vol 7, No 12.

Raghunathan, Bhanu (1991). "Premature Signing-Off Audit Procedures: An Analysis". Accounting Horizons

Reed, S.A., Kratchman, S.H., Strawser, R.H.(1994). Job Satisfaction, Organizational Commitment, and Turnover Intentions of United States Accountants: The Impact of Locus of Control and Gender. Accounting, Auditing \& Accountability Journal. Vol. 7, no. 1.pp 31-58

Rhode, J. G. (1978). The Independent Auditor's Work Environment: A Survey. Commission on Auditors. Responsibilities Research Study, 4, 175-184. New York: AICPA.

Setiawan, Ivan Aries dan Imam Ghozali. (2006). Behavioral Accounting Book: Concepts and Empirical Studies of Accounting Behavior. Diponegoro University Publisher Agency Semarang

Shapeero, M., Chye Koh, H., \& Killough, L. N. (2003). Underreporting and premature sign-off in public accounting. Managerial Auditing Journal, 18(6/7), 478-489. https://doi.org/10.1108/02686900310482623

Siegel, G., dan H.R. Marconi, (1989). Behavioral Accounting. South-Western Publishing, Co. Cincinnati, OH.

Silaban, A. (2011). Pengaruh Multidimensi Komitmen Profesional terhadap Perilaku Audit Disfungsional. Jurnal Akuntansi \& Auditing, 8(1), 1-94. Retrieved from https://www.neliti.com/id/publications/73634/pengaruhmultidimensi-komitmen-profesional-terhadapperilaku-audit-disfungsional

Solar, D., and D. Bruehl. (1971). "Machiavellianism and Locus of Control: Two Conceptions of Interpersonal Power”. Psychological Reports 29: 1079- 1082.

Spector, P. E. (1988). Development of the work locus of control scale. Journal of occupational psychology

Suryadi, A. (2002). Review Procedure and Quality Control And Locus of Control before Premature Termination of Audit Procedure, 15-32

Teerooven, \& International. (2006). Auditors ' Perceptions of Time Budget Pressure, Premature Sign-Offs and Under- Reporting of Chargeable Time: Evidence from a Developing Country Auditors ' Perceptions of Time Budget Pressure, Premature Sign Offs and Under-Reporting of Chargeable Time:, (October 2016). http://doi.org/10.1111/j.1099-1123.2006.0350.

Theodorus M. Tuanakotta (2000). Accounting Theory. Jakarta: LPFE UI

Waggoner, Jeri B and James D.Cashell (1991)."The Impact of Time Pressure on Auditors' Performance”. Ohio CPA Journal 50

Wahyudin, A., Anisykurlillah, I., \& Harini, D. (2011). Dysfunctional Audit Behavior Analysis: A Personal Characteristic Approach Auditor, 67-76.

Institut Akuntan Publik Indonesia. (2014). Professional Standards of Certified Public Accountants (SPAP). Edition May 2014. Publisher Public Accountant Association of Indonesia, Jakarta.

\section{AuthorProfile:}

Dr. Trinandari Prasetyo Nugrahantireceived herPh.D. at the University of Padjadjaran, Bandung in 2013. Currently, she is a lecturer in Perbanas Institute Jakarta, Indonesia. Since joining the ABFI Institute of Perbanas Jakarta, Trinandari has involved with studies related to developing curriculum, faculty member placement, improving and monitoring the learning process, responsible for achieving the goal in the study program, develop a connection between academic and practice community/industry especially in the accounting field.

Contact Information:

Graduate Program in Accounting,

ABFI Institute of Perbanas Jakarta,

Perbanas, Karet Kuningan, Setiabudi, Jakarta Selatan

Indonesia

12940 